\title{
Kategismusprediking in die \\ Nederduitsch Hervormde Kerk van Afrika
}

\author{
T F J Dreyer \\ Universiteit van Pretoria
}

\begin{abstract}
Doctrinal preaching in the Nederduitsch Hervormde Kerk van Afrika

The churches that sprung from the Reformation in the sixteenth century, had firmly established, by the turn of the century, doctrinal teaching as an important part of church life. There was to be doctrinal teaching during the Sunday afternoon service. This frequent preaching, however, deteriorated with time. This paper tries to reestablish the original purpose and function of doctrinal preaching, and evaluate its use for modern times. Finally the paper attempts to point out the significance of doctrinal teaching and how to implement it within the church today.
\end{abstract}

\section{Huldigingswoord}

Sedert 1967 was dit my voorreg om prof A D Pont van nader te leer ken. Aanvanklik was hy een van die leermeesters wat ons as studente ingelei het in die kennis van die Kerkgeskiedenis en die Kerkreg. Deur sy besondere kennis en aanbieding het hy by ons ' $n$ liefde vir ons reformatoriese erfenis gekweek. Vanaf 1983 het ek die geleentheid gehad om in die Fakulteit Teologie as kollega met hom saam te werk. Tydens informele gesprekke en akademiese debatte het veral sy fenomenale kennis van die teologie van die sestiende eeu telkens respek afgedwing. Gedurende die laaste aantal jare het ek ook die voorreg gehad om ten nouste met hom saam te werk op die vlak van die Kommissie van die Algemene Kerkvergadering. Hier het 
dit duidelik geword dat die reformatoriese teologie vir hom nie slegs teoretiese kennis is nie, maar dat hy vanuit daardie basis die teologiese lyne skerp kon deurtrek na die praktiese lewe en werk van die kerk in 'n nuwe situasie.

By geleentheid van sy emeritaat wil ek daarom graag hierdie artikel oor die prediking van die Heidelbergse Kategismus aan hom opdra. Op dié wyse wil ek erkenning verleen aan ons reformatoriese erfenis waarvoor hy so 'n groot kampvegter is.

\section{INLEIDING}

Die prediking van die Heidelbergse Kategismus het tans skynbaar vir predikante en gemeentelede, binne die kring van die reformatoriese kerke, 'n probleem geword. Die titels van enkele artikels wat in dié verband gepubliseer is, verwoord die skynbare verleentheid: 'Die kategismusprediking in die krisis' (Schulze 1988), 'Wat doen wij met de Heidelbergse Catechismus?' (Gerbrandy 1983) en 'Hoe kan daar dikwels oor die Kategismus gepreek word sonder om die mense weg te jaag?' (Dijkstra 1974). 'n Literatuurondersoek wat in dié verband gedoen is, het weinig resultate opgelewer. Gedurende die afgelope vyf jaar het op sowel Europese as Suid-Afrikaanse bodem geen wetenskaplike artikels oor dié onderwerp die lig gesien nie. Homiletiese handboeke wat die afgelope twee dekades verskyn het, gee geen of weinig aandag aan die prediking van die Kategismus (vgl inter alia Thomas 1976; Bijlsma 1977; Jonker 1973; Pieterse 1979; Fendt 1970). Hierdie verfloude belangstelling in die prediking van die Kategismus staan in skrille kontras met vroeëre homiletiese werke waar die prediking van die Kategismus prominente aandag geniet het (vgl bv Dijk 1955:406-435; Hoekstra 1975:369-377; Van Oosterzee 1895:360-366).

Die kwynende belangstelling in die prediking van die Kategismus het ook sy effek gehad binne die geledere van die Hervormde Kerk. Aanvanklik was predikante verplig om ten minste twaalf maal per jaar oor die Kategismus te preek, maar Engelbrecht (1979:98) was van mening dat dit in die huidige tydsgewrig te min is. Sedertdien het die situasie só verander dat predikante volgens Artikel XII van die Kerkwet (NHKA 1989) slegs verplig word om die Kategismus 'in volgorde aan die gemeente' uit te lè. Volgens verslae wat voor die Ringsvergaderings dien, blyk dit dat die prediking van die Kategismus nie meer reëlmatig deel van die prediking in die meeste gemeentes is nie. Kommer hieroor is ook verwoord tydens die jaarlikse Predikantevergadering van 1990. Teen hierdie agtergrond is dit gebiedend noodsaaklik dat die Hervormde Kerk hom sal vergewis van die noodsaaklikheid al dan nie van die gereelde prediking van die Heidelbergse Kategismus. Hierdie artikel is 'n poging om te probeer bepaal of die prediking van die Kategismus in ons dag nog relevant is en indien wel, hoe gereeld en op watter wyse dit aan die orde moet kom? 


\section{OORSPRONKLIKE BEDOELING EN FUNKSIE VAN DIE KATEGISMUS}

Die prediking van die Heidelbergse Kategismus vorm deel van die reformatoriese erfenis, waarvan die wortels herlei kan word na die sestiende eeu. Om enigsins 'n begrip te vorm waarom, in die wordingsjare van die reformatoriese teologie, aan die prediking van die Heidelbergse Kategismus so 'n hoë prioriteit toegeken is, sal daar eers vagestel moet word wat die oorspronklike bedoeling met die opstel van die Kategismus was.

Frederik III, keurvors van die Palts, het spoedig nadat hy keurvors geword het (1559) besef dat hy iets sal moet doen aan die verwarring en onenigheid op godsdienstige gebied.

Naas die stryd tussen die Rooms-Katolisisme en die Protestantisme het daar ná die dood van Martin Luther in 1546 ook groot onenigheid binne die Protestantisme ontstaan. Naas die randverskynsels van die Doperbeweging en die Spiritualiste, het Zwingliane, Calviniste en Lutherane hulle laat geld in onderlinge leerverskille en in kompetisie om invloed en mag.

(Oberholzer 1986:1)

Frederik was op grond van die Bybel daarvan oortuig dat hy sy hoë regeeramp nie van mense ontvang het nie, maar van God en dat hy daarom aan God verantwoordelikheid verskuldig is oor hoe hy regeer. Hy was van mening dat indien die regskape kennis van Gods Woord en die vrees vir die Almagtige ontbreek, 'dan sal vanweë die aangebore boosheid van die mens, alle burgerlike en kerklike regerings, ampte en verordeninge omvergewerp word' (Engelbrecht 1979:65). In sy voorrede by die eerste uitgawe word dit duidelik dat hy veral besorg was oor die opgroeiende jeug wat op 'n nalatige wyse opgevoed en onderrig word in skole sowel as kerke. Sonder die regte onderwys kan nòg die regering, nòg die huishoudings bestendig onderhou word. Predikers en skoolmeesters sal 'n vaste maatstaf moet hê hoe hulle in die onderrig van die jeug moet optree en nie na eie goeddunke die daaglikse onderrig onderneem of 'n verkeerde leer invoer nie (Oberholzer 1986:17).

Sy voorrede by die Latynse uitgawe fokus weer eens op die opvoeding en onderrig van die jeug. Die skole was in 'n toestand van verwaarlosing vanweë die feit dat daar geen vaste en eenvormige onderrig in die Christelike godsdiens was nie. Die Kategismus het ten doel dat predikers en skoolmeesters 'n sekere en vaste maatstaf kan hê waarvolgens hulle die jeug in kerke en skole kan onderrig 'en nie na eie goeddunke telkens nuwe dinge invoer of aan die jeug dinge oordra wat nie ooreenstem met die Woord van God nie...sodat hulle gewoond sal raak daaraan om dit in hulle lewe en optrede van toepassing te maak' (Oberholzer 1986:19). Dit wil dus voorkom asof die Kategismus aanvanklik veral die regte onderrig en opvoeding van 
die jeug volgens ' $n$ vaste verwysingsraamwerk ten doel gehad het. Die prediking van die Kategismus in die erediens kom eers spesifiek aan die orde in die voorrede tot die Kategismus toe die nuwe Kerkorde van die Palts in November 1563 gepromulgeer is en waarin die Kategismus opgeneem is. Vir die eerste keer is in hierdie publikasie die Kategismus opgedeel in lectio's en Sondagsafdelings. In hierdie voorrede word die ouer mense vir die eerste maal spesifiek ook as teikengroep vermeld omdat hulle 'onder die pousdom sonder Kategismus opgegroei het en maklik vergeet waaroor die Christelike geloof gaan' (Oberholzer 1986:20).

Riglyne vir die implementering van die Kategismus, wat in die voorrede gestel word, het na alle waarskynlikheid die bereiking van twee doelwitte in die oog gehad: Eerstens was daar 'n duidelike oogmerk om gemeentelede toe te rus met 'n parate kennis van die Kategismus. Die vrae en antwoorde moes gememoriseer word. Om dit te kon bereik, moes jongmense tuis en op skool die vrae leer, maar dit is ook voortdurend in die Kerk voorgelees en herhaal, waarskynlik omdat analfabetisme 'n redelike algemene verskynsel was. Die voorskrifte lui dat die Kategismus op alle Sondae deur kerklike ampsdraers, voor die aanvang van die gewone prediking, duidelik en verstaanbaar voorgelees word, op só 'n wyse dat dit in nege Sondae volgens die lectio-afdelings deurgelees word. Ná die prediking van die Kategismus, wat elke Sondagmiddag plaasgevind het, moes jongmense die vrae wat hulle nog nie kon bemeester nie, opsê. Jongmense moes ook die vrae wat in die voorafgaande prediking behandel is, herhaal (Oberholzer 1986:20-21). Die herhaalde voorlesing en repetering van vrae en antwoorde moes daartoe bydra dat gemeentelede die vrae en antwoorde kon memoriseer en paraat die geloofsinhoude verbaliseer.

Tweedens, naas die kennismotief, was daar ook 'n gerigtheid op die verstaan van die inhoude en die internalisering daarvan. Hierdie doelwit is verwesenlik deur die verpligte prediking van die Kategismus wat elke Sondagmiddag, aan die hand van die indeling in Sondagsafdelings, moes plaasvind. Sodoende is die Kategismus eenmaal per jaar deurgepreek (Oberholzer 1986:20-21). Die prediking van die Kategismus het die eenvoudige verklaring van die inhoude van die Woord op die oog gehad, met gepaardgaande vermanings 'sodat hulle gewoond sal raak daaraan om dit in hulle lewe en optrede van toepassing te maak' (Oberholzer 1986:19). Naas die bybring van 'n parate kennis deur onderrig en voorlesing, moes dit ook eksistensieel word deur middel van die prediking.

Twee duidelike doelwitte kan dus onderskei word 'namelijk die van explicatie en memorisatie. Het verklaren vind plaas in de preek...Het leren krijgt gestalte in het opzeggen van de vragen en antwoorden...' (Verboom 1987:119). Barnard $(1984: 8)$ is ook die mening toegedaan dat gosdienskennis in die Kategismus met die lewe verbind is. Aanvanklik was daar ook nie so 'n definitiewe skeiding tussen die 
kategese en die kategismusprediking nie; hierdie skeiding het eers later gekom (Pretorius 1967:10; Grobler 1983:16). Schulze (1988:27-29) toon tereg aan dat die skeiding tussen leer en geloof, objektiewe kennis en subjektiewe heilstoeëiening, stam uit die sewentiende-eeuse Ortodoksie. Dit is 'n probleemstelling wat vir die Reformasie vreemd was, omdat die saaklike leerinhoud self 'n pro me, of 'n pro nobis struktuur het. 'By Calvyn...adem kennis die intiem-persoonlike geur van jada, waarsonder geloof en godsvrug en 'n lewende verhouding met die Here nie moontlik is nie' (Schulze 1988:27).

'n Laaste saak wat in hierdie verband aandag verdien, is die funksie van die Skrifverwysings. Die Skrifverwysings was nie oorspronklik deel van die teks van die Kategismus nie, maar het daarop gevolg as ' $n$ 'opgawe van die vernaamste tekste soos dit ordelik in die voorgaande Kategismus verklaar is' (Oberholzer 1986:3). Die Skrifverwysings het ook met die loop van tyd talle wysigings ondergaan. Wat egter van belang is, is die oorspronklike funksie van die Skrifverwysings, naamlik dat dit gedien het as bevestiging en veral polemiese 'bewapening' van die uiteengesette leer (Schulze 1988:29). Gepaardgaande met die formalisering van die Skrifgesag in die sewentiende eeu, het die funksie van die Skrifverwysings verskuif vanaf die oorspronklike 'bevestiging' na ' $n$ bewys van die Skrifmatigheid daarvan (Graffmann 1961:650-651). Die strydvraag wat later ontstaan het (Remonstrante), naamlik of kategismusprediking Woordbediening is omdat dit nie per se vanuit 'n Skrifwoord vertrek nie, maar vanuit 'n belydenisgeskrif (Engelbrecht 1979:96), is in die tyd van die Reformasie nie as 'n spanning beleef nie.

Op grond van hierdie kort oorsig van die oorspronklike plek en funksie van die Kategismus, kan konkluderend enkele gevolgtrekkings gemaak word:

- Die onderrig en opvoeding van die jeug moes plaasvind aan die hand van die vaste maatstaf van die Ḳategismus om sodoende verwarring, willekeur en dwalinge teen te werk.

- Die Kategismus moes 'n verwysingsraamwerk bied waarbinne die gemeenskap ordelik en in gehoorsaamheid aan God moes lewe.

* Memorisering en 'n parate kennis is beoog deur gereelde voorlesing van die Kategismus in die Kerk, onderrig tuis en op skool. Repetering van die inhoude het 'n groot rol gespeel.

* Kategismusprediking moes nie net kategese wees nie. Alhoewel die grense tussen kategese en kategismusprediking aanvanklik vloeibaar was, het daar met die Kerkorde van Paltz reeds 'n onderskeid sigbaar geword tussen die kategese van die jongeres wat die inleiding tot die kategismusprediking was en eintlike kate- 
gismusprediking. Kategismusprediking moet daarom nie net onderwysing wees nie, maar ook toepassing, vermaning en vertroosting (Engelbrecht 1979:95).

- Volwassenes het mettergaan ook deel uitgemaak van die fokus van die onderrig en prediking van die Kategismus, omdat hulle onder die pousdom sonder die Kategismus opgevoed is. Dit het ook duidelik geword dat daar ' $n$ groot prys gestel is op die binding tussen liturgie en belydenis en dat die onderrig in die reformatoriese leer nie met die kategese afgehandel is nie, maar voortgesit moet word in die liturgie deur die prediking van die Kategismus (Engelbrecht 1979: 94).

- Daar was nie 'n spanning tussen die onderrig van die Kategismus en die Skrifgegewens nie.

- Prediking van die Kategismus op Sondagmiddag was aanvu'lend tot die Woordbediening elke Sondagoggend.

- Die kategismusprediking is gehandhaaf om dwaalleer uit die Kerk te weer en die eenheid van die Kerk op grond van die suiwere leer te bewaar (Grobler 1983:38-39).

\section{HISTORIESE ONTWIKKEI JNG}

Ná die vestiging van die Kategismus in die Palts het dit spoedig in wyer verband gevestig geraak. Die gebruik van die Kategismus is ook in Nederland oorgeneem. Aanvanklik is die Geneevse Kategismus en dié van á Lasco gebruik, maar dit is geleidelik, as gevolg van die vertaling van die Heidelbergse Kategismus deur Datheen, deur die Heidelberger vervang (Engelbrecht 1979:93). Die Konvent van Wezel (1568) en die Sinode van Emden (1571) laat 'n vrye keuse watter kategismus gebruik sal word. Die Nasionale Sinode van Dordrecht (1578) en dié te Middelburg (1581) bepaal dat die Nederlandse gemeentes die Heidelbergse Kategismus moes gebruik en die Waalse gemeentes die Kategismus van Genève. Die Nasionale Sinode van Den Haag (1586) besluit onomwonde dat voortaan slegs die Heidelbergse Kategismus gebruik moet word (Verboom 1987:112). Die Sinode van Dordrecht (1618-1619) bepaal:

De dienaars zullen alomme des Zondags, ordinaarlijk in de namiddagse predikatie, de somma der Christelijke leer in den Catechismus, die tegenwoordig in de Nederlandsche kerken aangenomen is, vervat, kortelijk uitleggen, alzoo dat dezelve jaarlijks mag geëindigd worden, volgens de afdeeling des Catechismus zelven daarop gemaakt.

(Pont 1981:184) 
Die vestiging van die gebruik van kategismusprediking het nie sonder moeite en teenstand verloop nie. Krasse bapalings wat die prediking van die kategismus verpligtend gemaak het, moes ingevoer word. Die Provinsiale Sinode van Deventer (1619) besluit byvoorbeeld dat die kategismuspreek gehou moet word 'al zouden alleen maar de gezinnen van de predikant en de schoolmeester en de schoolkinderen in de kerk zijn' (Verboom 1987:114). Achelis (1906:236) skets die probleme wat ondervind is met die kategismusprediking: 'Voortdurend rezen klachten over het slecht bezoek der namiddaggodsdienstoefeningen...In de Ommelanden werd nog in 1680 geklaagd, dat verscheidene predikanten in de namiddaggodsdienstoefeningen noch toehoorders noch antwoorders konden vinden'. Ongeag die aanvanklike teenstand, lyk dit tog asof die gebruik om op Sondagmiddag gereeld oor die Kategismus te preek, in die tweede helfte van die sewentiende eeu 'n gevestigde gebruik was.

Daar is ook gegewens wat daarop dui dat die prediker dikwels van die kansel afgeklim het ná die kategismuspreek en selfs die kennis van die ouer lidmate getoets het, terwyl hy onder hulle rondbeweeg het (Engelbrecht 1979:93). Voor en na die Sondagmiddagdiens het die kinders in die gemeente onderrig uit die Kategismus ontvang en is veral aandag gegee aan die vrae wat op die preekstoel behandel is (Pont 1981:253).

In die verdere historiese ontwikkeling het dit gou reeds duidelik geword dat daar aan die prediking van die Kategismus 'n bepaalde karakter toegeken is, naamlik dat dit prediking van die Woord moes wees. Die Remonstrante was van mening dat die Kategismus bloot 'n menslike geskrif was en dat slegs die Heilige Skrif gepreek kon word (Wagenaar 1909:393). Daarteenoor het die gereformeerdes die standpunt gehuldig dat die Kategismus in ooreenstemming met die Woord van God was (Achelis 1906:236). Die gevaar in hierdie standpunt is natuurlik dat aan die Kategismus dieselfde gesagas die Bybel toegeken kan word. Om dié beswaar tegemoet te kom is bepaal dat daar uit 'n Skrifgedeelte voorgelees moet word wat die Sondagsafdeling helder belig. Verder moes in die uitleg van die Kategismus telkens op Skriftuurlike bewysplekke teruggekom word (Engelbrecht 1979:96). Die karakter van die kategismusprediking as Woordbediening word ook gerēflekteer in die gebed voor die prediking van die Kategismus, waar gebid word dat God deur die Heilige Gees, verstand en wil sal verlig 'opdat het Woord dat gehoord wordt, recht verstaan wordt' (Verboom 1987:116). Die Heidelbergse Kategismus is gesien as 'n hulpmiddel by die verklaring en toepassing van die Skrif om sodoende mense in die ware geloof op te bou. Later word hierdie doelstelling aangetas as die kategismuspreek die karakter van 'n leerstellige betoog begin aanneem waarin baie predikers meer die 'orateur als den Leeraar vertoonen' (Verboom 1987:118). Verboom (1987:121) is ook van mening dat die uiteindelike instelling van kinderkatkisasie 
daarop dui dat die kategismusprediking nie die geskikte middel was om kinders mee te bereik nie. Die Sinode van Dordrecht (1618-1619) het dit ook openlik uitgespreek.

Die patroon van die kategismusprediking wat mettertyd gevestig geraak het, het sekere aspekte laat uitkristalliseer:

- Die kategismusprediking moes tydens die Sondagmiddagdiens, aan die hand van die Sondagsafdelings plaasvind, sodat dit jaarliks deurgepreek word.

- Dit was voluit Woordbediening, omdat dit gebaseer was op Skrifgedeeltes wat die gedeelte belig het.

- Nieteenstaande swak bywoning is dit verpligtend gemaak, omdat dit noodsaaklik geag is vir die opbou van die geloof, gegrond in die suiwer leer.

- Kategeseonderrig van die jeug was die aanloop tot en aanvullend by die kategismusprediking.

- Volwassenes moes ook deur die kategismusprediking bereik word. Ook hulle is ná die diens ondervra om sodoende by hulle 'n parate kennis van die Kategismus te verseker.

\section{DIE NEDERDUITSCH HERVORMDE KERK}

Die kerklike posisie in Suid-Afrika is van die begin af geskoei op die lees van die Nederlandse Hervormde Kerk. Oberholzer (1986:7) toon aan dat die prediking van die Kategismus gehandhaaf is ten spyte van louheid en swak bywoning. Die Algemene Kerkvergadering van 1829 het gereelde kategismusprediking 'n vaste agendapunt by kerkvisitasie gemaak. Die frekwensie van die kategismusprediking is mettertyd in beide die Nederduitse Gereformeerde Kerk (Dijkstra 1974:52) en in die Hervormde Kerk (Engelbrecht 1979:98) afgeskaal tot twaalf keer per jaar. Tydens die Algemene Kerkvergadering van 1967 word daar op aanbeveling van die Predikantevergadering die volgende besluit geneem: 'Dat dit noodsaaklik is dat die Heidelbergse Kategismus sover moontlik een maal per Sondag in die prediking vir die gemeente uitgelê sal word...sonder dat dit as 'n absolute verpligting sal geld' (NHKA 1967:23). Deur hierdie besluit word die indruk gewek dat vanaf die voorgeskrewe twaalf maal per jaar daar terugbeweeg word na die oorspronklike 'elke Sondag'. Die byvoeging tot die besluit dat dit nie as verpligting sal geld nie, het egter die deur geopen vir totale willekeur. Die frekwensie van kategismusprediking kon ná hierdie besluit nie meer afgedwing word nie. Hierdie onafdwingbaarheid van die frekwensie kom na vore in 'n verdere besluit van die Algemene Kerkvergadering: 'Die vergadering beveel aan dat waar daar twee eredienste op 'n Sondag ge- 
hou word, by die erediens sover moontlik aandag gegee sal word aan die kategismusprediking, aangesien kategismusprediking die beste vorm van voortgesette kategese is' (NHKA 1970:213). Hierdie afwatering van die voorgeskrewe frekwensie van kategismusprediking het uiteindelik gelei tot 'n wysiging van Artikel XII van die Kerkwet na sy huidige bewoording: 'Die Heidelbergse Kategismus word in volgorde aan die gemeente uitgele' (NHKA 1989:5).

In praktyk het hierdie formulering daartoe gelei dat in die Hervormde Kerk die prediking van die Kategismus in talle gemeentes deur predikante verwaarloos word, soveel so dat dit in sommige gemeentes weinig aan die orde kom. Predikante verweer hulle dikwels daarop dat hulle wel oor die kerkdike leerstukke preek sonder dat hulle dit uitdruklik aan die gemeente vermeld. So 'n hantering van die Kategismus is duidelik vér verwyderd van die oorspronklike gees en bedoeling.

Hierdie gees blyk uit ' $n$ navraag wat die Ring van Vereeniging tot die Kommissie van die Algemene Kerkvergadering rig oor die wenslikheid van die aankondiging van die Vraag van die Kategismus voor die prediking. Die Kommissie reageer daarop deur te stel dat hy dit wenslik ag 'dat die hele Sondagsafdeling van die Kategismus telkens voorgelees sal word' (NHKA 1969:35). 'n Ander navraag vanuit Die Ring van Pretoria handel weer oor oor die interpretasie van die woorde in volgorde'. Die Kommissie antwoord daarop dat dit beteken 'dat die kategismus sistematies in volgorde behandel sal word sonder dat daar tussenin oorgeslaan sal word of dat heen en weer uit die kategismus gepreek sal word' (NHKA 1978:118). Uit hierdie antwoorde van die Kommissie kan die afleiding gemaak word dat nie slegs die leerstellige inhoude van die Kategismus vir die gemeente van belang is nie, maar ook die formulering van die Vrae en die Antwoorde. Dit sluit aan by die oorspronklike bedoeling van die Heidelborger dat dit, soos reeds aangedui, deur die memorisering van die vrae, lidmate tot 'n parate kennis van die suiwere leer wou bring. Of die blote voorlees van die hele Sondagsafdeling wel hierdie parate kennis tot gevolg sal hê, is 'n ope vraag. Feit is dat die Kommissie deur hierdie antwoord wel klem lê op die kennis van die bewoording van die Kategismus. Ten opsigte van die interpretasie van die woorde 'in volgorde', bevestig die Kommisssie daardeur dat nie slegs die inhoude nie, maar ook die samehang daarvan, soos dit in die 'sisteem' van die Kategismus beslag gekry het, vir die regte kennis van belang is. Met hierdie uitspraak stel die Kommissie dat ook die 'sisteem' waarbinne die leerinhoude verwoord is, in die kategismusprediking van belang is. Die bedoeling van die Kerk met Artikel XII is dus duidelik dat die prediking van die Kategismus binne die samehang van die 'sisteem' moet plaasvind en dat dit ook by lidmate 'n parate kennis van die Kategismus se bewoording moet bevorder. 
Uit hierdie kort oorsig kan enkele gevolgtrekkings gemaak word:

- Die prediking van die Kategismus het in die Hervormde Kerk 'n agteruitgang beleef vanweë die feit dat daar nie meer ' $n$ voorgeskrewe mininmum ten opsigte van die frekwensie geld nie.

- Die Kerk stel, nieteenstaande skynbare ontwyking deur predikante, nogtans die eis dat kategismusprediking eksplisiet beteken dat die bewoording van die vrae en antwoorde, asook die navolging van die 'sisteem' vir die Kerk van belang is.

- Kategismusprediking moet die gemeente (ook volwassenes) post-kategeties begelei tot 'n parate kennis van die Kategismus, asook tot die internalisering van die leerinhoude in 'n lewe van geloof.

\section{DIE PROBLEMATIEK VAN KATEGISMUSPREDIKING VANDAG}

Talle redes word tans gegee waarom die prediking van die Kategismus in ons tyd problematies geword het. Daar sal gepoog word om die belangrikste besware kortliks te behandel.

\subsection{Kategismusprediking is nie Woordbediening nie}

Die vraag van die Remonstrante of Kategismusprediking Woordbediening is, is nog steeds lewend. 'n Homiletiese grondreël binne die reformatoriese tradisie is dat alle prediking in die Kerk Skrifprediking moet wees (Barnard 1984:16). Hier is dit van belang om ook te let op die ander grondreël van die reformatoriese teologie, naamlik die onderskeid tussen die Skrif as die norma normans en die belydenisskrifte as die norma normata. In hierdie verband is die opmerking van Wethmar (1977:261) ter sake, naamlik: 'Die kerklike leer in die Reformatoriese sin van die woord laat sy gesag langs die hermeneutiese weg van die uitleg geld.' Wanneer die predikant ook in sy gewone prediking, volgens die ondertekeningsformule, aan die belydenis van die Kerk gebind is, beteken dit nie 'n dogmatiese dwang op die prediking nie. Ter wille van die orde in die Kerk word die prinsipiële openheid van die kerklike belydenis nie binne die kader van die amptelike prediking in die gemeente geskep nie, maar via die weg van 'n kerklike gravamen (Dreyer 1985:383).

Die binding van die prediking aan die belydenis beteken dus nie per se dat die belydenis hoër as die Skrif geag word nie. Dieselfde argument is van toepassing op die Kategismusprediking. Al verskil is dat die tema vir die prediking nie ' $n$ Skrifteks is nie, maar wel die tema van die Kategismus. Temaprediking in die Kerk is nie ' $n$ vreemde verskynsel nie, trouens Pieterse (1985:88) het aangetoon dat die meeste 
preke tekstematiese preke is. In wese kom dit daarop neer dat die predikant vanuit sy eksegese van 'n bepaalde gedeelte sy eie tema formuleer, wat dan die basis van die prediking vorm. Die nuwere eksegetiese metodes waar die teks in sy strukturele verband ontleed word, lei ook daartoe dat dikwels oor die hele perikoop gehandel word, met 'n tema as basis vir die prediking. Die blote aankondiging van 'n teksvers waarborg dus nie noodwendig die Skrifgebondenheid van die prediking nie: 'Die skrifteks self is egter nie die hoogste doel nie...hier word dit reeds duidelik dat die skopus van die prediking wyer is as die teks. Die skopus van die prediking is God self in die totaliteit van sy openbaring' (Dreyer 1989:366).

Kategismusprediking is in 'n sekere sin temaprediking, met dié verskil dat die Kerk in sy belydenisskrif reeds die tema geformuleer het, op grond van die Kerk se hermeneutiese verstaan van die Skrif. Elke kategismuspreek, soos elke ander preek en so ook die Kategismus self, sal voortdurend weer sy gesag langs die hermeneutiese weg van die uitleg moet toets. Die kategismuspreek sal daarom, aan die hand van die tema van die kategismus, nogtans slegs sy gesag kan behou as dit ook in die kategismuspreek die Skrifinhoude waarop dit gefundeer is hermeneuties reflekteer. Jonker (1976:131) stel dat die kategismuspreek nie as preek gediskwalifiseer kan word nie omdat die belydenis op ' $n$ baie bewuste manier daarin na vore kom. Volgens hom is die belydenis in die protestantse tradisie nie iets abstraks of onfeilbaar nie, maar doodeenvoudig ' $n$ hermeneutiese beslissing van die kerk oor die manier waarop die Skrif verstaan moet word. In die lig van hierdie opmerkings is die heswaar dat kategismusprediking nie Woordbediening is nie, blote haarklowery.

\subsection{Die historiese gebondenheid}

'n Volgende beswaar wat gewoonlik teenoor die kategismusprediking ingebring word, is dat dit in 'n bepaalde kultuurkleed gegiet is en daarom as produk van 'n sekere tyd en situasie nie meer vandag relevant is nie (Barnard 1984:16-17; Gerbrandy 1983:290). Hierdie beswaar kan net so van toepassing gemaak word op die prediking van 'n Skrifgedeelte. Dit is juis die uitdaging vir die prediker om die boodskap van die teks hermeneuties uit sy kultuurkleed en taalsimbole vir die gemeente van vandag in 'n nuwe situasie en met nuwe taalsimbole so oor te dra dat hulle oor die grense van tyd en taal heen God hoor spreek. Hierdie eis van hermeneutiese verstaan en vertolking geld ook onverkort vir die prediking van die Kategismus: 'Die wirkliche Treue der Übernahme [des Bekentnisses] realiseert sich gerade darin dass die alte Wahrheit in Korrespondenz zu den Fragen gesetzt wird die den heutigen Menschen hewegen' (Thielicke, in Gerbrandy 1983:290). 
Gerbrandy toon ook enkele begrippe aan wat via die verskillende vertalings van die Kategismus ander betekenisinhoude verkry het en opnuut ingeklee moet word (1983:292-303). Hy pleit dan ook tereg dat die teks van die Kategismus met sy verskillende vertalings, soos die teks van die Bybel tekskrities en eksegeties ontleed moet word. Die publikasie van Oberholzer (1986) kan in dié verband vir die uitleg van die Kategismus tot groot hulp wees. Die teologiese inhoude van die Kategismus sal ook met die oog op die prediking hermeneuties vertolk moet word. Die Sistematiese Teologie staan hier voor die geweldige uitdaging om die Kategismus vir ons eie tyd opnuut te vertolk en te verwoord. So 'n eietydse teologiese kommentaar op die Kategismus sal die prediking van die Kategismus in 'n nuwe situasie stimuleer.

\subsection{Die gebondenheid aan 'n antwoordsisteem}

Die kritiek word uitgespreek dat die Kategismus gebou is op 'n vaste sisteem wat op elke vraag 'n perfekte antwoord wil gee. So 'n sisteem wurg die lewe dood. Prediking moet ook nie op elke vraag 'n antwoord wil gee nie (Barnard 1984:18). Indien hierdie 'sisteem' van die Kategismus tot 'n voorwaarde vir geloof verhef word, is die genoemde beswaar geldig. Dit was egter nie die oorspronklike bedoeling met die Kategismus nie. Geloof is nie afhanklik van 'n sisteem nie, maar die oomblik wanneer die belydenis 'ek glo' uitgespreek word en die persoon word tot verantwoording geroep oor die inhoud van sy geloof, kom daar outomaties 'n samehang en bepaalde sisteem ter sprake. Die Kategismus het sy ontstaan gehad as 'n leerboek, maar dit het gegroei tot 'n belydenisgeskrif.

Zulk een tot belijdenisgeschrift geworden werk heeft minstens twee functies die o $\mathrm{i}$ door Berkouwer zeer verantwoord zijn samengevat door het woord 'hoop'; het belijden is (a) - naar binnen toe -: het door de geloof de gelovigen aan elkaar en voor God uitspreken dat er grond is en blifft voor hoop...en (b) - naar buiten - een rekenschap geven van die hoop (1 Petr 3:15) en dit alles in een min of meer kernachtige vorm waarin men elkaar erkent. Maar juist bij een belijdenisgeschrift-leerboek mag een derde functie niet vergeten worden: (c) samenvating van het geloof van de enkeling; noch het complex van heterogene geschriften dat wij de Bijbel noemen; noch zelfs 'the core of Biblical realism' (Kraemer) is zonder meer eenvoudig; verantwoorde samenvatting biedt de enkeling steun, helpt om hem een 'levend lid' te worden van de Kerk die belijdt.

(Gerbrandy 1983:290) 


\subsection{Rasionele appel}

Die aksent wat die Kategismus plaas op die regte kennis, word dikwels as beswaar geopper omdat dit te veel die klem plaas op die rasionele (Barnard 1984:19). Hierdie beswaar moet gesien word in die lig van ' $n$ vroeëre argument dat die skeiding tussen kennis en geloof ' $n$ latere probleem is en nie deel van die oorspronklike verwysingsraamwerk van die reformatoriese teologie was nie. Die Kategismus wil inderdaad kennis en insig meedeel, maar dan kennis as eksistensiële geloofskennis. Engelbrecht (1979:78-79) toon genoegsaam aan dat die Kategismus nie oor allerlei waarhede wil praat nie, maar al sprekende die gelowige persoonlik wil konfronteer met die lewende waarheid self. Jonker (1976:131) is ook van mening dat kategismusprediking nie bloot intellektuele leerprediking is nie, want in die protestantse sin van die woord is 'leer' allermins iets intellektueels wat niks met die mens se hart te make het nie. Volgens hom lê die Heidelbergse Kategismus juis getuienis daarvan af dat wat daarin as leer aangebied word, 'iets deur-en-deur eksistensieels is wat niks anders wil wees nie, as die verkondiging van die heilswoord waardeur 'n mens gered word' (Jonker 1976:131). Dit blyk uit die aanslag van die vraag-en-antwoordmetode wat gerig is op die individu (jou) en die inhoud wat telkens afgestem word op die nut, bate en betekenis wat dit vir die gelowige het. Die beswaar teen die rasionele aanslag van die Kategismus is dus nie 'n inherente gegewene daarvan nie, maar moet veeleer gerig word teen die adres van die prediker, wat deur sy aanbieding geloofswaarhede tot starre dogmatiese en rasionele insigte laat verword.

\section{KATEGISMUSPREDIKING VANDAG}

\subsection{Noodsaaklikheid}

Die redes wat gegeld het vir die noodsaaklikheid van die opstel van die Heidelbergse Kategismus, geld vandag met groter dringendheid. In 'n nuwe bedeling in SuidAfrika dui die voorlopige projeksies daarop dat Christelik-nasionale onderwys deur ' $n$ meer neutrale onderwysbeleid vervang sal word, waarin die Christelike karakter nie meer vanselfsprekend sal wees nie. Kragtens Artikel $X$ van die Kerkwet (NHKA 1989:4) aanvaar die Kerk mede-verantwoordelikheid vir die opvoeding en die onderwys van die jeug in 'n Christelik-nasionale gees, in huisgesin en skool. In die verlede was die Kerk in die bevoorregte posisie dat die owerheid in sy onderwysbeleid hierdie siening van die Kerk bevorder het. In 'n nuwe bedeling sal die Kerk waarskynlik sonder die vennootskap van die owerheid hierdie verantwoordelikheid alleen moet dra. Om dit te kan doen sal daar weer aan ouers en kinders, soos ten tyde van die opstel van die Kategismus, 'n vaste raamwerk gebied moet word waarbinne die gemeenskap ordelik en in gehoorsaamheid aan God kan lewe. 
Die feit dat in die Hervormde Kerk kinderkategese en kategismusprediking formeel van mekaar geskei is, asook die feit dat die Heidelbergse Kategismus in die kategesehandboeke van die Kerk nie volledig en eksplisiet aan die orde kom nie, bring mee dat die Kategismus by baie jonger lidmate 'n onbekende boek word. Die inrigting en metode van onderrig in die kategesehandboeke is ook nie doelbewus afgestem op 'n memorisering van die vrae en antwoorde van die Kategismus nie. Dit lei daartoe dat daar by baie jonger lidmate 'n onvermoë is om die inhoud van hulle geloof paraat te verwoord. Hierdie onvermoë maak dikwels van hulle gewillige slagoffers van die teologiese dwalings van ons tyd. In die lig hiervan is dit noodsaaklik dat naas die kategeseprogram, lidmate deur die prediking van die Kategismus weer ' $n$ vaste verwysingsraamwerk gebied word.

\subsection{Metode}

Soos aangetoon het die blote prediking van die Kategismus nie die gewenste effek gehad om aan die kinders die nodige kennis van die Kategismus oor te dra nie. Dit het juis daartoe aanleiding gegee dat die kategese los van die kategismusprediking 'n selfstandige plek verkry het. Dit blyk daarom noodsaaklik dat 'n parate kennis van die Kategismus, of vereenvoudigde leerboek, in die kategese groter klem moet kry. Daarnaas moet die kategismusprediking as postkategese weer tot sy reg kom. Die blote vlugtige voorlees van die Sondagsafdeling, soos deur die Kommissie voorgestel, waarborg egter nog geensins dat die hoorders daardeur die inhoud sal memoriseer nie, trouens dit lyk na wensdenkery. Aanvullend tot die prediking van die Kategismus sal daar ander metodes bedink moet word om lidmate te begelei tot ' $n$ meer parate kennis van die geloofsinhoude. Die gebruik wat mettergaan ontwikkel het om ook ouer lidmate ná die prediking te ondervra, kan in 'n moderne onderrigmetode omskep word. Dit is ook uit die historiese ontwikkeling duidelik dat die Sondagmiddagdiens wat aan die prediking van die Kategismus gewy is, ' $n$ ander karakter en inrigting gehad het. Naas die prediking van die Kategismus was dit af gestem op die bybring van kennis deur vrae te vra. Die prediking van die Kategismus kan vandag ook op die wyse aangevul word deur besprekingsgroepe as voorbereiding tot, of nabetragting van die kategismusprediking te benut.

\subsection{Karakter}

Vanuit die resultate van die ondersoek blyk dit dat die prediking van die Kategismus voluit Woordbediening moet bly. Om dit te kan verwesenlik beteken nie noodwendig dat 'n Skrifgedeelte as teks aangekondig hoef te word nie. As Skriflesing 
kan 'n gedeelte of gedeeltes wat die inhoud van die betrokke Sondagsafdeling die beste belig, voorgelees word. Die teks van die Kategismus sal as 'n historiese teks eksegeties ontleed en teologies vertolk moet word. Op grond van hierdie voorarbeid kan die prediker ' $n$ tema formuleer wat die intensie van die gedeelte met die oog op die gemeente die beste verwoord. Hierdie geformuleerde tema word dan die tema van die kategismusprediking. In die loop van die prediking sal die vraag en antwoord van die Kategismus verduidelik moet word en sal dit hermeneuties sy begronding en gesag in die reflektering van Skriftuurlike gegewens moet vind. Soos die gewone prediking, sal ook kategismusprediking ingerig en aangebied moet word, nie as 'n dogmatiese lesing nie, maar as geloofswaarhede wat die gemeente eksistensieel betrek.

\subsection{Frekwensic en volgorde}

Die gedwonge voorskrif van kategismusprediking wat elke Sondag moet plaasvind, moet gesien word in die lig van die feit dat kategese en kategismusprediking aanvanklik nie van mekaar geskei is nie. Met die formele skeiding en volwaardige plek wat die kategese in die loop van die geskiedenis verkry het, moet die frekwensie van kategismusprediking, in die lig van die postkategese, telkens opnuut aan die hand van praktiese omstandighede oorweeg word. Afwisseling is ook 'n belangrike oorweging. Om die prediking van die Kategismus in ere te herstel, is voorskrifte ten opsigte van die frekwensie tog noodsaaklik. 'n Ideaal van die deurwerk van die Kategismus in 'n rotasie van eẹn maal elke drie jaar, lyk na 'n opsie wat enersyds genoeg ruimte laat vir afwisseling, maar andersyds tog die nodige reëlmaat in die kategismusprediking sal bring. Die bepaling in die Kerkwet wat die volgorde van die Kategismus wil behou, is noodsaaklik omdat die inhoude van die Kategismus juis binne dié bepaalde samehang verstaan moet word.

\section{Literatuurverwysings}

Achelis, E C 1906. Praktische Theologie. Utrecht: Kemink.

Barnard, A C 1984. Kategismusprediking. Skrif en Kerk 5, 3-22.

Bijlsma, R 1977. De preek. Kampen: Kok.

Dijk, K 1955. De dienst der prediking. Kampen: Kok.

Dijkstra, H 1974. Hoe kan daar dikwels oor die Kategismus gepreek word sonder om die mense weg te jaag? In die Skriflig 8, 52-62.

Dreyer, T F J 1985. Die dogmatiese binding van die prediking. HTS 41, 378-386. 
Dreyer, T F J 1989. 'n Poging tot 'n herdefinisie van die prediking binne die raamwerk van die Reformatoriese teologie. HTS 45, 350-369.

Engelbrecht, B J 1979. Temas rondom die Reformasie. Pretoria: HAUM.

Fendt, K 1970. Homiletik. Berlin: De Gruyter.

Gerbrandy, S 1983. Wat doen wij met de Heidelbergse Catechismus? NedThT 37, 290-303.

Graffmann, H 1961. Geschichte der Entstehung und Methodik des Unterrichts im Heidelherger Katechismus. Neukerken: Neukirchner Verlag.

Grobler, C S 1983. Kategismusprediking - Is dit Skrifprediking? MTh-verhandeling. Potchefstroomse Universiteit vir Christelike Hoër Onderwys.

Hoekstra, T 1975. Gereformeerde Homiletiek. Amsterdam: Bolland.

Jonker, H 1973. En toch preken. Nijkerk: Callenbach.

Jonker, W D 1976. Die Woord as opdrag. Pretoria: NG Kerkboekhandel.

Nederduitsch Hervormde Kerk van Afrika 1967. Notule van die Vyf-en-vyftigste Algemene Kerkvergadering. Pretoria: NHKA.

-- 1969. Handelinge van die Kommissie van die Algemene Kerkvergadering Oktober tot Desember 1969. Pretoria: NHKA.

--- 1970. Notule van die Ses-en-vyftigste Algemene Kerkvergadering. Pretoria: NHKA.

--. 1978. Handelinge van die Kommissie van die Algemene Kerkvergadering Julie tot September 1978. Pretoria: NHKA.

--- 1989. Kerkwet en Bepalings. Pretoria: NHKA.

Oberholzer, J P 1986. Die Heidelbergse Kategismus. Pretoria: KITAL.

Pieterse, H J C 1979. Skrifverstaan en prediking. Pretoria: NG Kerkboekhandel.

--- 1985. Verwoording en prediking. Pretoria: NG Kerkboekhandel.

Pont, A D 1981. Die historiese agtengronde van ons kerklike reg, Deel 1. Pretoria: HAUM.

Pretorius, L A 1967. Die Heidelbergse Kategismus. BD-skripsie, Universiteit van Pretoria.

Schulze, L F 1988. Die kategismusprediking in die krisis. In die Skriflig 22, 24-31.

Thomas, J 1976. Homiletische hulplijnen. 's-Gravenhage: Boekencentrum.

Van Oosterzee, J J 1895. Praktische Theologie, Eerste Deel. Utrecht: Kemink.

Verboom, W 1987. De catechese van de Reformatie en de Nadere Reformatie.

Amsterdam: Buijten \& Schipperheijn.

Wagenaar, L H 1909. Van strijd en overwinning: De groote Synode van 1618 op 19, en wat haar voorafging. Utrecht: Ruys.

Wethmar, C J 1977. Dogma en verstaanshorison. Amsterdam: Rodopu. 